\title{
Further observations concerning the effects of hypophysectomy on the gastric mucosa of the rat
}

\author{
G. P. CREAN, R. D. E. RUMSEY, AND SYLVIA M. WHEELER \\ From the Medical Research Council Clinical Endocrinology Unit, 2 Forrest Road, Edinburgh, the Gastro- \\ intestinal Centre, Southern General Hospital, Glasgow, and the Department of Medicine, the Western Infirmary, \\ Glasgow
}

SUMMARY Hypophysectomy in rats markedly reduced the weight and surface area of the stomach as well as the volume (mass) of the gastric mucosa and the total parietal and total peptic cell populations.

The parietal cell population was reduced by about $50 \%$, and this effect was due entirely to the reduction that occurred in the total surface area of the stomach $(50 \%)$; the average number of parietal cells per unit area, which reflects the number of parietal cells in the gastric glands, was not affected. The peptic cell population was reduced by about $90 \%$, the factors responsible being a reduction in the average number of peptic cells per unit area $(70 \%)$ as well as the reduction that occurred in the surface area of the stomach. The disproportionate effect of hypophysectomy on the cell populations was thus due to the reduction in the number of peptic cells per unit area; this effect implies that hypophysectomy had caused a reduction in the number of the peptic cells in the gastric glands.

Whatever the mechanisms involved these results were due to a direct effect of pituitary deprivation on the stomach, since they could not be accounted for simply by the inhibition of somatic growth that follows hypophysectomy in rats. Thus the experiment included a group of sham hypophysectomized rats whose somatic growth was inhibited to the same extent as that of the hypophysectomized animals by deliberate underfeeding. While underfeeding reduced the surface area of the stomach $(20 \%)$ and the total peptic cell population $(25 \%)$, as well as exerting a marginal effect on the parietal cell population, these effects were much smaller in magnitude than those of hypophysectomy; moreover underfeeding did not affect the number of peptic cells in the gastric glands.

The results confirm that the pituitary gland exerts a strong influence on the growth of the gastricmucosa.

It has long been believed that the endocrine system may influence the growth of the gastric mucosa (Spence and Witts, 1939; Haeger, Jacobson, and Kahlson, 1953). In a previous experiment carried out in this laboratory it was found that hypophysectomy markedly reduced the weight and surface area of the stomach as well as the volume (mass) of the gastric mucosa and the total parietal cell population of the stomach in rats (Crean, 1968). Analysis of the data obtained in that experiment suggested that hypophysectomy had retarded the overall growth of the gastric mucosa and that the parietal cell population had been reduced in simple proportion to the reduction that occurred in the Received for publication 30 June 1971. mass of the secretory tissue as a whole; no observations were made on the peptic cells (Crean, 1968).

However, there is evidence to suggest that the peptic cells of the stomach are extremely susceptible to endocrine deprivation since they show profound involutional changes after hypophysectomy or adrenalectomy (Baker and Abrams, 1954; Corpron, 1966). These observations suggest that the peptic cell population, like the parietal cell population, might be reduced after hypophysectomy and the present experiment was carried out in order to examine this possibility.

Somatic growth ceases abruptly after hypophysectomy in the rat, so that any limitation in visceral growth that occurs after this procedure could be due 
not to pituitary deprivation per se, but simply to a general limitation in organ growth imposed by the inhibition in the growth of the organism as a whole. The present experiment was designed to allow for this effect by comparing hypophysectomized rats with sham hypophysectomized animals whose somatic growth was inhibited to the same extent by deliberate underfeeding; a group of sham hypophysectomized rats allowed to feed ad libitum were included as controls. Detailed observations were made on the stomachs of all the animals in the experiment, including estimates of the total parietal and total peptic cell populations.

\section{Methods}

A homogeneous sample of 18 male Wistar rats within the weight range of $120 \pm 5 \mathrm{~g}$ was supplied by the Charles River Breeding Laboratories Inc., Boston, Massachusetts, USA. The animals were hypophysectomized or sham hypophysectomized in the proportion of $1: 2$ on the same day in Boston according to a predetermined random order and shipped by air to Edinburgh where they arrived within 24 hours of operation. Hypophysectomy was performed by the parapharyngeal route. By 'sham hypophysectomy' is meant an operation which is identical to that performed when the pituitary is to be removed, up to and including the making of a burr hole in the base of the skull; in the sham procedure the pituitary is left in situ whereas it is removed by suction when an actual hypophysectomy is to be performed.

On arrival in the laboratory the sham hypophysectomized animals were randomly allocated to treatment either by feeding ad libitum or by underfeeding so that the experiment consisted of three groups, namely, sham hypophysectomized fed ad libitum (group I), sham hypophysectomized underfed (group II), and hypophysectomized fed ad libitum (group III) rats; for convenience the three groups will be designated respectively as 'controls' (group I), 'underfed' (group II), and 'hypophysectomized' (group III). The three groups were caged separately and maintained in the same room for the duration of the experiment. Each animal was weighed daily and all had free access to a $5 \%$ solution of dextrose saline in tap water with added vitamins for their fluid requirements. The diet consisted of rat cake homogenized with milk and glucose and orange slices sprinkled with glucose; this was provided in bulk twice daily to the control and hypophysectomized groups, whereas the underfed animals were fed individually once daily. The purpose of underfeeding was to maintain the body weight of the underfed animals at the same level as that of the hypophysectomized rats; it was carried out on an empirical basis, and the amount of food allowed to each of the underfed animals varied from day to day according to its body weight and the mean body weight of the hypophysectomized animals on the same day. With practice, the amount of food required to be given to each of the underfed animals was judged fairly accurately so that the mean body weight of the underfed group was reduced to that of the hypophysectomized group on the third day of the experiment, and the growth curves for the two groups were very similar thereafter (Figure 1).

The experiment was terminated on the 49th postoperative day by killing all the animals one by one by exposure to chloroform. The pituitary fossa was carefully examined with a hand lens at necropsy, and it was confirmed that the pituitary was intact in all

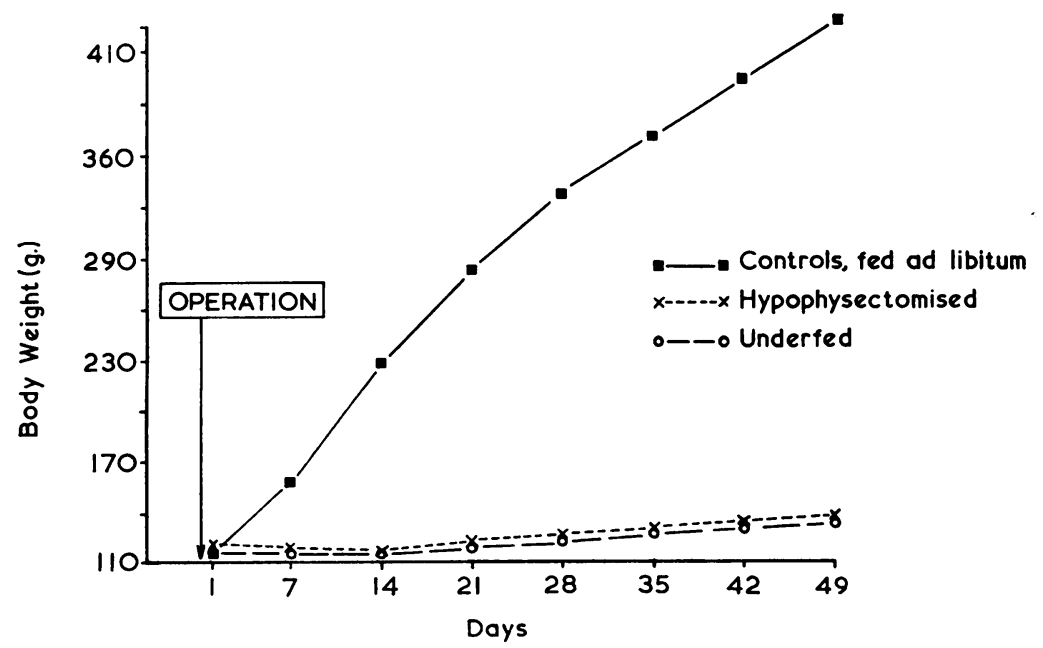

Fig. 1 The mean body weight curves for the three groups during the experimental period; all the operations were carried out on the same day, the 'control' and underfed groups being sham hypophysectomized. 
the sham hypophysectomized animals, and that complete hypophysectomy had been carried out in all the animals in group III. The adrenals and testes were removed from each animal and stored in $10 \%$ formol-saline; these organs were all weighed subsequently on the same day after being dried by swabbing. The stomach was removed as quickly as possible after death and the following observations were made on each organ, according to methods previously described (Cox and Barnes, 1945; Card and Marks, 1960; Crean, 1968); the weight of the whole stomach, the surface area of the fundus, the height and volume of the fundic mucosa, the average count of parietal and peptic cells per unit area, and the total parietal and total peptic cell populations. Briefly, the stomach was opened along the lesser curve, pinned flat with the serosal surface downwards in such a way as to eliminate mucosal folds and fixed in the flattened position by immersion in formolsaline. After fixation the whole stomach was weighed after being swabbed dry, and the surface area of the fundus was measured by planimetry. Two wholethickness strips were then excised from sites corresponding to the middle of the anterior and posterior walls of the stomach, each strip extending from the transverse ridge to the antrum; longitudinal sections cut at right angles to the surface of the mucosa were prepared from each strip for the histological observations and were stained by the method of Marks and Drysdale (1957). Parietal and peptic cells were counted at a magnification of approximately $\times 1,400$ using a calibrated graticule $0.1 \mathrm{~mm}$ broad in the eyepiece of a projecting microscope. A single 'count' represented all the parietal and peptic cell nuclei seen in a column of tissue $0.1 \mathrm{~mm}$ broad extending from the base to the surface of the mucosa; such a column would underlie a unit of the surface area of the mucosa with dimensions represented by the width of the column and the thickness of the section under examination. An 'average count per unit area' was then calculated for each stomach after the observed values had been corrected for section thickness and nuclear overestimation (Abercrombie, 1946), the correction factors required being derived from direct measurements (Marengo, 1944; Card and Marks, 1960; Crean, 1968); providing that cell counts are carried out under constant conditions and without observer bias, the 'average count per unit area' must represent the number of cells present in the gastric glands. The 'average count per unit area' was then referred to the total surface area of the fundus to give an estimate of the total parietal and peptic cell populations. The volume of the fundic mucosa was calculated as the product of the surface area of the fundus and the mean height (or thickness) of the mucosa; since the density of a cell is about unity, mucosal volume approximates mucosal mass.

The exact methods used have already been described in detail (Crean, 1968, 1969); observer errors are of the order of $5 \%$ and it has been shown that the sampling procedure gives reliable estimates of the total parietal and total peptic cell populations in the rat. The principal source of error is subjective bias on the part of the observer; this was eliminated by having all the sections relabelled by a third party according to a set of random numbers so that the observer had to examine each section as an 'unknown'.

\section{Results}

The data were analysed by analysis of variance and the value for the variance ratio $F$ is given for each observation (Table I); when significant variations

\begin{tabular}{|c|c|c|c|c|c|}
\hline Observation & $\begin{array}{l}\text { Six Controls } \\
\text { (Group I) }\end{array}$ & $\begin{array}{l}\text { Seven Underfed } \\
\text { Rats } \\
\text { (Group II) }\end{array}$ & $\begin{array}{l}\text { Seven Hypophy- } \\
\text { sectomized Rats } \\
\text { (Group III) }\end{array}$ & $\begin{array}{l}\text { Variance Ratio } \\
F\end{array}$ & $D ; P=0.05$ \\
\hline $\begin{array}{l}\text { Initial body wt }(\mathrm{g}) \\
\text { Final body wt }(\mathrm{g}) \\
\text { Total stomach wt }(\mathrm{mg}) \\
\text { Surface area of fundic }\left(\mathrm{cm}^{2}\right) \\
\text { Height of fundic mucosa }\left(\mathrm{mm}^{2}\right) \\
\text { Volume of fundic mucosa }\left(\mathrm{mm}^{3}\right) \\
\text { Total pariet al cell population }\left(\times 10^{\circ}\right) \\
\text { Total peptic cell population }\left(\times 10^{\circ}\right) \\
\text { Parietal count per unit area } \\
\text { Peptic count per unit area } \\
\text { Adrenal weight }(\mathrm{mg}) \\
\text { Testes weight }(\mathrm{mg})\end{array}$ & $\begin{array}{l}122 \pm 2 \\
425 \pm 25 \\
1,748 \pm 121 \\
13 \cdot 6 \pm 0.8 \\
0 \cdot 357 \pm 0.007 \\
458 \pm 27 \\
61 \cdot 4 \pm 5 \cdot 5 \\
120 \cdot 2 \pm 5 \cdot 6 \\
19 \cdot 55 \pm 1 \cdot 0 \\
39 \cdot 2 \pm 1 \cdot 0 \\
64.9 \pm 3 \cdot 0 \\
3,966 \pm 26\end{array}$ & $\begin{array}{c}122 \pm 1 \\
134 \pm 2 \\
1,455 \pm 35 \\
10 \cdot 7 \pm 0 \cdot 4 \\
0 \cdot 339 \pm 0 \cdot 012 \\
383 \pm 13 \\
45 \cdot 8 \pm 2 \cdot 0 \\
89 \cdot 6 \pm 4 \cdot 4 \\
19 \cdot 3 \pm 0 \cdot 7 \\
37 \cdot 0 \pm 1 \cdot 0 \\
31 \cdot 0 \pm 1 \cdot 1 \\
2,915 \pm 113\end{array}$ & $\begin{aligned} & 112 \pm 2 \\
& 137 \pm 1 \\
& 839 \pm 14 \\
& 6.4 \pm 0.2 \\
& 0.296 \pm 0.010 \\
& 190 \pm 9 \\
& 28.9 \pm 1 \cdot 0 \\
& 12 \cdot 0 \pm 2 \cdot 6 \\
& 21 \cdot 3 \pm 0.9 \\
& 8.9 \pm 1 \cdot 8 \\
& 12 \cdot 0 \pm 0.7 \\
& 471 \pm 89\end{aligned}$ & $\begin{aligned} 10.2 \mathrm{P} & <0.01 \\
1,401 \mathrm{P} & <0.001 \\
397 \mathrm{P} & <0.001 \\
52 \mathrm{P} & <0.001 \\
11.1 \mathrm{P} & <0.01 \\
67 \mathrm{P} & <0.001 \\
26 \mathrm{P} & <0.001 \\
174 \mathrm{P} & <0.001 \\
\text { N.S. } & \\
141 \mathrm{P} & <0.001 \\
225 \mathrm{P} & <0.001 \\
406 \mathrm{P} & <0.001\end{aligned}$ & $\begin{array}{c}9 \cdot 9 \\
23 \cdot 4 \\
350 \\
2 \cdot 7 \\
0 \cdot 052 \\
96 \\
17 \cdot 0 \\
22 \cdot 7 \\
- \\
7 \cdot 8 \\
9 \cdot 4 \\
478\end{array}$ \\
\hline
\end{tabular}

Table I Results (mean 士 standard error)

${ }^{1}$ Counts per unit area refers to the estimated number of cells underlying a unit of the surface area of the mucosa with the dimensions $100 \mu$ by $4.9 \mu$ approximately.

'N.S. = not significant. 
occurred the group means were further tested by Tukey's method to detect significant differences at the $5 \%$ level or less (Tukey, 1953).

\section{BODY WEIGHT}

On the day that the operations were actually performed, the body weights of the animals selecte 1 for the experiment fell within the weight range of $120 \pm 5$ grams. However, when the experiment was begun 24 hours afterwards the body weight of the hypophysectomized group was significantly less than either of the other two groups; this difference may be attributed to the lesser food intake of the hypophysectomized animals while in transit from Boston to Edinburgh, and to the more severe disturbance in general health caused by hypophysectomy. The body weight curves of the hypophysectomized and underfed animals were very similar throughout the course of the experiment (see Fig. 1) and there were no significant differences between them with respect to final body weight on the day that the experiment was terminated; thus any difference that occurred between these two groups with respect to the observations on the gastric mucosa could not be attributed to differences in their rate of somatic growth. As might be expected, the final body weight of the control animals which were allowed to feed ad libitum (group I) was very much greater than the mean weight of either of the other two groups.

\section{STOMACH WEIGHT}

Although the weight of the stomach was greater in the control animals $(1,748 \pm 121 \mathrm{mg})$ than it was in the underfed group $(1,455 \pm 35 \mathrm{mg})$, this effect was not statistically significant; however, the weight of the stomach was significantly reduced by hypophysectomy $(839 \pm 14 \mathrm{mg})$.

\section{SURFACE AREA AND HEIGHT AND VOLUME \\ OF THE FUNDIC MUCOSA}

Both underfeeding and hypophysectomy exerted striking effects on the surface area of the stomach which showed a progressive reduction as between the control $\left(13.6 \pm 0.8 \mathrm{~cm}^{2}\right)$, underfed $(10.7 \pm$ $\left.0.4 \mathrm{~cm}^{2}\right)$, and hypophysectomized $\left(6.4 \pm 0.2 \mathrm{~cm}^{2}\right)$ animals, the group means being significantly different in each case. On the other hand, the height (or thickness) of the mucosa was not affected by underfeeding, although it was markedly reduced by hypophysectomy.

Although the volume of the fundic mucosa was greater in the control animals $\left(458 \pm 27 \mathrm{~mm}^{3}\right)$ than it was in the underfed group $\left(383 \pm 13 \mathrm{~mm}^{3}\right)$, this effect failed to reach statistical significance; however, mucosal volume was significantly reduced by hypophysectomy $\left(190 \pm 9 \mathrm{~mm}^{4}\right)$.
THE PARIETAL AND PEPTIC CELL POPULATIONS

\section{Average count per unit area}

The results obtained for the average parietal and peptic cell counts per unit area were strikingly different, the parietal count being unaffected by either of the experimental treatments, whereas the peptic count was greatly reduced by hypophysectomy. Thus there were no significant differences in the number of parietal cells per unit area between the controls $(19.5 \pm 1 \cdot 0)$, underfed $(19.3 \pm 0.7)$, and the hypophysectomized groups $(21 \cdot 3 \pm 0 \cdot 9)$. Similarly, there were no significant differences in the number of peptic cells per unit area as between the control $(39.2 \pm 1.0)$ and underfed animals $(37.0 \pm 1.0)$; however, there was a very marked reduction in the number of peptic cells per unit area after hypophysectomy $(8.9 \pm 1 \cdot 2)$. This result suggests that there was a reduction in the number of the peptic cells in the gastric glands after hypophysectomy.

\section{Total parietal cell population}

Although the total parietal cell population was greater in the control animals $(61.4 \pm 5.0$ million) than it was in the underfed group $(45 \cdot 8 \pm 2 \cdot 0$ million), this effect just failed to reach statistical significance. However, there was a significant reduction in the parietal cell population after hypophysectomy $(28.9 \pm 1.0$ million); since the parietal count per unit area was not affected, this effect was due entirely to the reduction in the total surface area of the stomach (50\%) that occurred after hypophysectomy.

\section{Total peptic cell population}

The total peptic cell population showed a progressive reduction as between the control $(120 \cdot 2 \pm 5 \cdot 6$ million), underfed (89.6 \pm 4.4 million), and hypophysectomized $(12.0 \pm 2.6$ million) groups, the group differences reaching statistical significance in each instance. In the case of the underfed animals the reduction in the total peptic cell population was due entirely to the reduction in the total surface area of the stomach $(20 \%)$ that occurred with underfeeding; as mentioned above the number of peptic cells per unit area was not affected by underfeeding. The much greater reduction in the total peptic cell population after hypophysectomy was due to a combination of two factors, namely, the reduction in the average number of peptic cells per unit area $(70 \%)$ as well as the reduction in the total surface area of the stomach $(50 \%)$ that occurred in this group.

Weight of the adrenals and testes

There was a progressive reduction in the weight of 
the paired adrenals as between the control (64.9 \pm $3.0 \mathrm{mg})$, underfed $(31.0 \pm 1.1 \mathrm{mg})$, and hypophysectomized groups $(12.0 \pm 0.7 \mathrm{mg})$, the group differences being significant in each case; the weight of the paired testes showed a similar trend. These results confirm that the pituitary had been completely removed in the hypophysectomized animals and show, not unexpectedly, that the development of these organs in the rat may be impeded as a result of underfeeding.

\section{Discussion}

The results obtained in the present experiment confirm previous conclusions (Spence and Witts, 1939; Haeger, Jacobson, and Kahlson, 1953); Crean, 1968) that the pituitary is in some way responsible for maintaining the growth of the gastric mucosa, and that this effect is not due simply to the inanition that follows the removal of the pituitary in the rat. Thus, the weight of the stomach, the surface area, height (thickness), and volume (mass) of the fundic mucosa and the total parietal and total peptic cell populations were significantly reduced in hypophysectomized as compared either to underfed or control animals fed ad libitum. Moreover, the values obtained for all the gastric observations in the hypophysectomized animals were smaller than those obtained in the underfed group, except for mucosal thickness and parietal count per unit area; since the somatic growth of the two groups was similar, the differences between them with respect to the growth of the gastric mucosa must have been due to the effects of hypophysectomy.

However, the most striking result of the present experiment was the disproportionate reduction in the peptic cell population relative to the reduction in the parietal cell population after hypophysectomy. The parietal cell population was reduced by about $50 \%$, this effect being due solely to the reduction in the surface area of the fundus that occurred after hypophysectomy. The total peptic cell population was reduced by about $90 \%$, the factors responsible being a reduction in the number of peptic cells per unit area as well as the reduction in the total surface area of the fundus; the disproportionate effect of hypophysectomy on the two cell populations was thus entirely due to the reduction in the number of peptic cells per unit area. Provided that cell counts are carried out under standard conditions and without subjective bias the 'average count per unit area' must represent the number of parietal or peptic cells in the gastric glands; since the observations on the two cell types were made under the same conditions and on the same histological sections the preferential reduction in the peptic count per unit area must represent either a real effect of hypophysectomy in reducing the number of peptic cells in the gastric glands, or, alternatively the number of peptic cells was underestimated. Erroneously low counts might be due to difficulty in recognizing the peptic cells as a result of the profound cytological alterations that they are known to undergo after hypophysectomy (Baker and Abrams, 1954; Corpron, 1966). We were able to confirm these cytological abnormalities and took great care in identifying the peptic cells on this account; moreover, we found no significant disagreement in the results obtained independently by two of us with long experience of cell counting when the peptic cell counts were repeated twice using freshly stained sections on each occasion. Thus, while the possibility of error cannot be positively excluded, this seems an unlikely explanation for our results.

The disproportionate reduction in the peptic cell population after hypophysectomy is in keeping with the results obtained in previous studies concerning the functional and cytological changes that occur in the digestive glands following endocrine deprivation. Although gastric secretion as a whole is greatly reduced after hypophysectomy in the rat, cat, and dog (Baker and Abrams, 1954; Kyle and Welbourn, 1956; Cutting, Dodds, Noble, and Williams, 1937; Jacobson and Magnani, 1964), there is some evidence to suggest that the secretion of pepsin is reduced to a greater degree than the secretion of acid. Thus, gastric acid secretion was reduced by about $60 \%$ at six weeks after hypophysectomy in dogs, and was reduced by about $90 \%$ at 14 weeks after hypophysectomy; by contrast pepsin secretion was virtually abolished at six weeks after hypophysectomy and thereafter the capacity to secrete pepsin was apparently abolished completely (Jacobson and Magnani, 1964). Moreover, the pepsin-secreting cells of the stomach show marked involutional changes characterized by a reduction in cell size, smaller nuclei, fewer mitochondria, and loss of zymogenic granules after hypophysectomy in rats, and these changes are accompanied by histochemical evidence of diminution in ribonucleic acid content and of a generalized reduction in oxidative enzymatic processes (Baker and Abrams, 1954; Abrams and Baker, 1954); it is of interest that similar but less severe changes occur in the zymogenic cells of the salivary glands and pancreas following hypophysectomy (Baker and Pliske, 1957; Schapiro, Wruble, and Britt, 1970). Furthermore, hypophysectomy causes marked ultrastructural changes in the peptic cells with a loss of ribosomes and profound involutional changes in the ergastoplasm and Golgi apparatus suggesting impaired protein synthesis (Corpron, 1966). In contrast to the 
profound changes induced in the zymogenic cells of the stomach and other glands the parietal cells show relatively slight involutional changes after hypophysectomy; these include a reduction in cell size and some reduction in enzymatic processes, as well as a reduction in the calibre of the intracellular canaliculi and distortion of intracellular microvilli (Baker and Clark, 1961; Corpron, 1966).

While all these effects are presumably due to hormonal deficiency following pituitary deprivation it is not known whether the mechanism responsible is deficiency of the pituitary hormones per se, or secondary deficiency of the secretions of one or more of the other endocrine organs (Crean, 1968; see Crean, 1963; Schapiro et al, 1970). It is not known either why hypophysectomy should affect the peptic cells to a greater degree than the parietal cells. One possibility is that the peptic cells are simply more susceptible to structural damage as well as to reduction in their overall growth and development than are the parietal cells in the face of marked alterations in the growth or secretory behaviour of the gastric mucosa as a whole. This explanation may be supported by the fact that the two cell types have been disproportionately affected in at least two other experimental situations. Thus, bilateral adrenalectomy induced structural changes in the peptic cells that were similar to those induced by hypophysectomy, although the parietal cells were not affected (Baker and Bridgman, 1954); similarly the total peptic cell population was considerably reduced after vagotomy in the rat, whereas the parietal cell population was virtually unchanged (Crean, Gunn, and Rumsey, 1968). An alternative possibly is that the disproportionate reduction in the peptic cells represents a specific effect of hypophysectomy on their growth and development; if this explanation is correct it ought to be possible to 'spare' the peptic cell population by administering appropriate hormone replacement treatment after hypophysectomy. Experiments are being carried out along these lines with the aim of deciding which of the proposed explanations for the effect of hypophysectomy on the peptic cell population is correct, and in the hope of providing further information as to the mechanisms by which the pituitary influences the overall growth of the gastric mucosa as a whole.

References

Abercrombie, M. (1946). Estimation of nuclear population from microtome sections. Anat. Rec., 94, 239-247.

Abrams, G. D., and Baker, B. L. (1954). The cytology and secretory activity of gastric zymogenic cells after ablation of ductless glands. Gastroenterology, 27, 462-468.

Baker, B. L., and Abrams, G. D. (1954). Effect of hypophysectomy on the cytology of the fundic glands of the stomach and on the secretion of pepsin. Amer. J. Physiol., 177, 409-412.

Baker, B. L., and Bridgman, R. M. (1954). The histology of the gastrointestinal mucosa (rat) after adrenalectomy or administration of adrenocortical hormones. Amer. J. Anat., 94, 363397.

Baker, B. L., and Clark, R. H. (1961). Influence of hypophysectomy on oxidative enzymes and size of parietal cells in gastric mucosa. Proc. Soc. exp. Biol. (N.Y.), 106, 65-67.

Baker, B. L., and Pliske, E. C. (1957). Endocrine regulation of zymogenic cells. Symp. Soc. exp. Biol., 11, 329-344.

Card, W. I., and Marks, I. N. (1960). The relationship between the acid output of the stomach following 'maximal' histamine stimulation and the parietal cell mass. Clin. Sci., 19, 147-163.

Corpron, R. E. (1966). The ultrastructure of the gastric mucosa in normal and hypophysectomized rats. Amer. J. Anat., 118, 5389.

Cox, A. J., and Barnes, V. R. (1945). Experiment al hyperplasia of the stomach mucosa. Proc. Soc. exp. Biol. (N.Y.), 60, 118-120.

Crean, G. P. (1963). The endocrine system and the stomach. Vitam. and Horm., 21, 215-280.

Crean, G. P. (1968). Effect of hypophysectomy on the gastric mucosa of the rat. Gut, 9, 332-342.

Crean, G. P. (1969). Hyperplasia of the gastric mucosa. In NonInsulin Producing Tumors of the Pancreas, edited by L. Demling and R. Ottenjahn, pp. 141-151. Thieme, Stut tgart.

Crean, G. P., Gunn, A. A., and Rumsey, R. D. E. (1968). The effects of vagotomy on the gastric mucosa of the rat. Scand. J. Gastroent., 4, 675-680.

Cutting, W. C., Dodds, E. C., Noble, R. L., and Williams, P. C. (1937). Pituit ary control of aliment ary blood flow and secretion, gastric secretion and blood flow in hypophysectomised animals. Proc. roy. Soc. B, 123, 49-59.

Haeger, K., Jacobsohn, D., and Kahlson, G. (1953). Atrophy of the gastrointestinal mucosa following hypophysectomy or adrenalectomy. Acta physiol. scand., Suppl. III, 30, 161-169.

Jacobson, E. D., and Magnani, T. J. (1964). Some effects of hypophysectomy on gastrointestinal function and structure. Gut, $5,473-479$.

Kyle, J., and Welbourn, R. B. (1956). The influence of the adenohypophysis and the adrenal cortex on gastric secretion in the rat. Brit. J. Surg., 44, 241-247.

Marengo, N. P. (1944). Paraffin section thickness; direct method of measurement. Stain Technol., 19, 1-10.

Marks, I. N., and Drysdale, K. M. (1957). A modification of Zimmerman's method for differential staining of gastric mucosa. Stain Technol., 32, 48-49.

Schapiro, H., Wruble, L. D., and Britt, L. G. (1970). The effect of hypophysectomy on the gastrointestinal tract. Amer. J. dig. Dis., 15, 1019-1030.

Spence, A. W., and Witts, L. J. (1939). Substitution therapy in hypopituitarism. Quart. J. Med., 8, 69-77.

Tukey, J. W. (1953). The problem of multiple comparisons. As discussed by W. P. Snedecor (1956). In Statistical Methods, 5th ed., p. 251. Iowa State College Press, Ames, Iowa. 